\title{
THE MISSING LINK: ACCESS TO JUSTICE IN ENVIRONMENTAL MATTERS
}

\author{
Attila Pánovics, PhD, Assistant professor \\ University of Pécs, Faculty of Law \\ Hungary, Pécs, H-7622 48-as tér 1. \\ panovics.attila@ajk.pte.hu
}

\begin{abstract}
It is widely recognized that environmental protection, social benefits and economic issues must go hand in hand. In the European Union, Environment Action Programmes (EAPS) have guided the development of EU environmental policy since the 1970s, and they have strengthened the achievement of environmental goals and the integration of environmental interests in other EU policy areas. Given their joint responsibility, EU environmental policy provides added value both for the EU and its Member States.
\end{abstract}

Until the end of 2020 the $7^{\text {th }}$ EAP is the agreed framework of environmental policy-making, and discussions are underway on developing the $8^{\text {th }}$ EAP. Between 2014 and 2020, some progress has been made towards achieving the goals of the programme. For example, the $7^{\text {th }}$ EAP provided more predictability of environmental policy and facilitated Member States' policy coordination. Nevertheless, the evaluation of the $7^{\text {th }}$ EAP proves that EU legislation is going in the right direction, but the impacts cannot be seen with actions on the ground.

The environmental acquis of the EU continues to grow, but the efforts are insufficient to implement it. Broad difficulties with the coherent implementation of environmental policy can be perceived at national level, too. That is the main reason why different stakeholders (particularly environmental NGOS) play a decisive role in environmental policy-making, implementation and enforcement. The evidence base indicates that the involvement of the members of the public can reduce the enforcement deficit of EU environmental law, but more needs to be done at all levels.

In 1998, the EU and all the Member States signed the Aarhus Convention on environmental rights, including access to justice in environmental matters. On 17 March 2017, the Compliance Committee (ACCC) found the EU to be in violation of the Convention by failing to provide members of the public with access to the EU courts. On the other side, the Commission adopted a proposal on access to justice in environmental matters in 2003, but the proposal did not gather sufficient support from the national governments. The Commission therefore withdrew the proposal in 2014. Nonetheless, the Commission has delayed remedying this issue, even contrary to calls by international bodies and its fellow institutions. 
In October 2019, the European Council called upon the Commission to present at the latest by early 2020 an ambitious and focused proposal for the $8^{\text {th }}$ EAP (2021-2030), and underlined that the new programme must address environmental governance, such as public participation and access to justice. Hopefully, the missing link of EU environmental legislation will be resolved by the EU institutions as soon as possible.

Keywords: environmental rights, Aarhus Convention, access to justice

\section{INTRODUCTION}

In 2020, Europe faces environmental challenges of unprecedented scale and urgency. As a pioneer of industrialisation, Europe has played a pivotal role in shaping global changes. Today, global trends such as diverging population trends and increasingly severe consequences of climate change are intensifying many challenges in Europe, while rapid technological change brings new risks and uncertainties. ${ }^{1}$ Looking ahead, these developments look set to continue increasing pressures on the environment. Making sense European environment's state, trends and prospects requires an integrated approach that acknowledges the complex drivers and implications of environmental change. Urgent sustainability challenges and barriers require systemic solutions, but our systems are characterised by path-dependency, linked to the fact that system elements (infrastructures, technologies, knowledge, etc.) have often developed together over decades.

The call for fundamental transitions is not new. The European Environment Agency $(\mathrm{EEA})^{2}$ has regularly made such call in its state and outlook reports (SOERs). The $6^{\text {th }}$ SOER identifies serious gaps between the state of the European environment and existing EU policy targets. This 2020 edition aims to inform discussions on the EU's 2030 policies, including trajectories to 2050 and beyond. ${ }^{3}$ It can be seen that many environmental trends in the EU continue to be a cause for concern, ${ }^{4}$ not least due to insufficient implementation of environmental legislation. EU environmental law, despite being one of the most comprehensive of

$1 \quad$ Changing disease burdens and risks of pandemics are also good examples. On 2030 January, the WHO Director-General declared the novel coronavirus (2019-nCOV) outbreak a public health emergency of international concern. The coronavirus disease (COVID-19) impacts the global population in drastic ways, and strains health systems worldwide

2 In close collaboration with the European Environmental Information and Observation Network (Eionet) and its 32 member countries, the EEA provides sound and independent information on the environment to support European environmental governance, and inform the general public

3 The European environment - state and outlook, Knowledge for transition to a sustainable Europe, European Environment Agency, 2019, p. 7, [https://www.eea.europa.eu/soer], accessed 23. March 2020

4 SOERs show serious implementation gaps in key areas, such as biodiversity, water, air and waste 
the world, ${ }^{5}$ is still not properly enforced and implemented. Weak implementation of environmental legislation generates high economic, societal and environmental costs, and it creates an uneven playing field for businesses. ${ }^{6}$ The total costs of current implementation gaps are estimated at around EUR 55 billion annually. ${ }^{7}$

The understanding of systemic change has important implications for environmental governance as well. Environmental governance in the EU is not limited to the interventions of the EU institutions and the EU Member States. Environmental challenges call for a 'whole-of-society' approach in which all citizens and their organisations have a role to play. Europeans are highly supportive of environmental protection. As annual Eurobarometer surveys show, there is strong support for the role of EU legislation in protecting the environment, ${ }^{8}$ and this allows more proactive environmental interventions and closer engagement of citizens in supporting the actions of EU institutions and Member States. Citizens' expectations for living in a healthy environment must be met, and this will require renewed focus on implementation as a cornerstone of environmental policies.

\section{THE PUBLIC PARTICIPATION PRINCIPLE}

Public participation is an important theme of contemporary environmental policy and law at all levels. The protection of the environment is mostly a matter of common or public concern. Environmental problems directly affect every individual, community, group, association and other organisation. Degradation and deterioration of the environment, and measures to counter it, have an impact not only on human health and well-being, but also the general quality of life.

It is a fundamental shortcoming that environmental concerns are systematically underrepresented. The environment itself has no voice and nor do future generations. ${ }^{9}$ Therefore, instruments, procedures and mechanisms need to be developed

5 In the past 50 years the EU has adopted a substantial and diverse range of environmental measures aimed at improving the quality of the European environment. The body of environmental legislation has grown significantly since the second half of the 1960 s

6 For example, illegal waste operators can under-cut legitimate waste industry by disposing of waste at illegal sites.

7 COWI and Eunomia, Study: The costs of not implementing EU environmental law, Final Report, 2019, [https://ec.europa.eu/environment/eir/pdf/study_costs_not_implementing_env_law.pdf], accessed 21. March 2020

8 Special Eurobarometer 501: Attitudes of European citizens towards the Environment, Summary, December 2019, p. 28, [https://data.europa.eu/euodp/en/data/dataset/S2257_92_4_501_ENG], accessed 18. March 2020

9 As Advocate General Sharpston noted at the hearing in the Trianel Case before the Court of Justice of the EU (C-115/09 Bund für Umwelt und Naturschutz Deutschland, Landesverband Nordrhein-Westfalen 
to allow as broad a discussion on environmental issues as possible. It is widely recognized that the involvement of the public in environmental matters is essential to the promotion of sustainable development, democracy and a healthy environment. If the members of the public can make more effective use of their democratic rights of participation in the field of environmental protection, public participation leads to an improved openness of governance, more extensive rights of the members of the public, and through all these, greater public awareness on environmental issues, encouraging citizens to rethink their behaviours and lifestyles.

Individuals and their organisations acting in the public interest, such as in relation to the environment, contribute to the improvement of the level of environmental protection. They have to work together to find meaningful solutions to today's environmental problems, including citizens, communities and their associations. Participatory democracy is a pre-requisite for the realisation of sustainable development, ${ }^{10}$ and participatory mechanisms establish a reliable basis for making better decisions that benefit all stakeholders, since it is generally supposed that a wider range of considerations can be taken into account. ${ }^{11}$ Additionally, public participation methods improve the legitimacy of decision-making as, inter alia, the participation of citizens can potentially make decisions more democratic. ${ }^{12}$ Finally, the members of the public have a crucial role to play to close the implementation gap. The practical and effective application of existing rules is one of the most serious challenges that environmental laws face today.

In theory, all members of society can contribute to the development of environmental policy and law. The can serve as the 'eyes and ears' of specialized monitoring institutions and other state organs. People can participate in decision-making as individuals or organised in associations and other non-governmental organisations (NGOs) for environmental protection. Owing to the complexity of environmental issues, their greater expertise and organised efforts, environmental NGOs are in a better position to enforce the interests of the public than those of individuals. They are the products of "social self-organisation" emancipating civic values

eVv Bezirksregierung Arnsberg EU:C:2011:289), 'the fish cannot go to court'

10 Agenda 21 also stated that "one of the fundamental prerequisites for the achievement of sustainable development is broad public participation in decision-making"; see Cameron, J.; MacKenzie, R., Access to Environmental Justice and Procedural Rights in International Institutions, in: Boyle, A. E.; Anderson M. R. (eds.), Human Rights Approaches to Environmental Protection, Oxford University Press, 1996, p. 151

11 Richardson B. J.; Razzaque, J., Public Participation in Environmental Decision-Making, in: Richardson, B. J.; Wood, S. (eds.), Environmental Law for Sustainability, Hart Publishing, Oxford, 2006, p. 165

12 Ebbesson, J., The Notion of Public Participation in International Environmental Law, Yearbook of International Environmental Law, vol. 8, 1997, pp. 75-81 
and grassroots activities, protecting pluralism and diversity in society, providing services with flexibility, establishing the mechanisms by which the government and the market can be held accountable by the public, and pursuing a change in the collective mentality.

Public participation cannot be imagined without active citizens and their organisations. The lack of financial and human resources, and insufficient capacitybuilding also raise numerous problems. The risk remains that public participation is only pro forma, without a serious chance for the citizens to influence environmental decision-making. Truly available rights can motivate and empower people to participate in decision-making in an informed and meaningful manner. The greatest challenge has always been to ensure political support among countries for the adoption of a legally binding instrument at international level.

\section{THE AARHUS CONVENTION}

More than 20 years after its adoption in 1998, the Aarhus Convention ${ }^{13}$ remains a leading model example of the application of the concept "environmental democracy" as enshrined in Principle 10 of the Rio Declaration on Environment and Development. When the Convention entered into force in 2001, the former Secretary-General of the United Nations, Kofi Annan called "the Aarhus Convention the most ambitious venture in environmental democracy undertaken under the auspices of the United Nations". ${ }^{14}$ The Convention was open to ratification (acceptance, approval or accession) by States and by regional economic integration organisations. ${ }^{15}$

The adoption of the Aarhus Convention marked a milestone in the development of 'environmental rights'. ${ }^{16}$ This moment was a historical landmark and an unprecedented example of the international community's quest towards more effective protection of the environment. As a fundamental step forward in the protection of the right of every person to a clean and healthy environment, it also demonstrated

13 Convention on Access to Information, Public Participation in Decision-making and Access to Justice; the text of the Convention is available at [http://www.unece.org/env/pp], accessed 02. March 2020

14 [https://www.unece.org/env/pp/statements.05.11.html], accessed 02. March 2020

15 The 'REIO clause' recognizes the scope of the EU's activities at international level; see Odermatt, J., The Development of Customary International Law by International Organizations, International and Comparative Law Quarterly, vol. 22, Issue 2, 2017,, p. 18

16 It is worth recalling that the adoption of the Aarhus Convention was the result of an extraordinary experiment in multilateral cooperation between governments and environmental NGOs. The Convention negotiations were open to the participation of NGOs, and they served, in many cases, as the driving force behind the negotiations 
the commitment of the international community to involving people in decisions that affect their daily lives.

The Convention does not create a substantive right to a clean and/or healthy environment. Rather, it concentrates on the procedural dimensions to assert the right "to live in an environment adequate to [...] health and well-being". ${ }^{17}$ With other words, the main function of procedural law is to be a provider for substantive law, aiming at its full effect and enforcement. ${ }^{18}$ The basic concept of the Convention is that wherever public authority is exercised, there should be right for individuals and NGOs. When public authorities fail to respect rights and obligations under environmental laws, the public can hold them accountable.

Currently, the most advanced instrument on environmental rights is still the regional Aarhus Convention. It is a legally binding international agreement establishing concrete rights of citizens to get engaged into environmental policymaking and enforcement. The Convention gives the right to the members of the public not only to be informed about environmental issues and have access to environmental information, but also to be involved in decision-making procedures and have access to justice in environmental matters. The Compliance Committee of the Aarhus Convention (ACCC) has developed a significant practice in relation to all three 'pillars' of the Convention which are the main elements of Principle 10 of the Rio Declaration as well. The findings of the Compliance Committee provide important guidance for governments, academia, practitioners, and civil society on how to shape future instruments and enforce current ones. ${ }^{19}$

The Parties to the Aarhus Convention are required to make the necessary decisions so that public authorities ${ }^{20}$ will contribute to environmental rights to become effective. The practical application of the Convention and its principles takes time and requires a change of behaviour of many, citizens and environmental NGOs, public administrations and national authorities, courts and tribunals. The real challenge is to avoid a gap between the spirit of the Aarhus Convention and the day-to-day practice on the ground.

The great value of the Convention is not only in the integration of human right and the environment, but also in the model it provides for similar action in other

$17 \quad$ See paragraph 7 of the Preamble

18 Darpö, J., Principle 10 and access to justice, in: Krämer, L.; Orlando, E. (eds.), Elgar Encyclopedia of Environmental Law, Edward Elgar Publishing, 2018, p. 400

19 Andrusevych, A.; Caroline Jo, C., Sustainable development concerns at the Aarhus Convention Compliance Committee, in: Cordonnier Segger, M.-C. (ed.): Sustainable Development Principles in the Decisions of International Courts and Tribunals, Routledge, 2017, p. 737

20 The Aarhus Convention defines public authorities in a broad and functional way 
regions of the world. It has served in many countries as a stimulation to make environmental laws even more democratic. Additionally, on 4 March 2018, member states of the UN Economic Commission for Latin America and the Caribbean (ECLAC), focusing on the implementation of Principle 10 of the Rio Declaration, adopted a new treaty, entitled Regional Agreement on Access to Information, Participation and Justice in Environmental Matters in Latin America and the Caribbean. The Agreement was formally adopted at Escazú, Costa Rica, with the active participation of eight Caribbean countries. It is open for signature until 26 September 2020, and is subject to the ratification, acceptance or approval of 33 countries. ${ }^{21}$ It is the only binding international treaty stemming from the UN Conference on Sustainable Development (Rio+20), the first regional environmental agreement in that region, and the first in the world containing specific provisions on environmental human rights defenders.

\section{ACCESS TO JUSTICE IN ENVIRONMENTAL MATTERS}

The right to an effective remedy is a generally accepted principle of modern legal systems, and it is enshrined in international treaties as well as national constitutions. Sustainable Development Goal (SDG) 16 in the United Nations 2030 Agenda for Sustainable Future (Agenda 2030) also aims to provide access to justice for all and build effective, accountable and inclusive institutions at all levels. ${ }^{22}$ At EU level, the right to an effective remedy is laid down in Article 47 of the Charter of Fundamental Rights. This gives rise to an obligation on the part of the Member States to provide, in accordance with Article 19(1) TEU, remedies sufficient to ensure effective legal protection in the fields covered by EU law.

Rights can only be effective and implementable if there are adequate and sufficient redress mechanisms to uphold them when they are omitted or violated. The right of access to justice is the backbone of environmental rights. The importance of wider public participation in shaping environmental policy and the advantages of better access to courts for citizens and their organisations are widely recognized. The empowerment of the public in the context of sustainable development requires access to effective judicial and/or administrative procedures to challenge measures and to claim compensation.

Access to justice in environmental matters is a fundamental means through which citizens and non-governmental organisations (NGOs) can support the enforcement and the implementation of policies and laws to protect the environment.

\footnotetext{
21 The Agreement shall be ratified by 11 countries to enter into force

22 [https://www.un.org/ruleoflaw/sdg-16/], accessed 02. April 2020
} 
Without the timely and equitable implementation of access to justice, the rights under the Aarhus Convention will only remain promises. Environmental rights are interrelated and interdependent; in the context of Principle 10, access to justice has been understood broadly to encompass not only access to courts, but also to other non-judicial or administrative means and alternative dispute resolution mechanisms. ${ }^{23}$ Where environmental complaints or petitions are not dealt with through administrative procedures, legal action is available as a last resort in solving environmental disputes. ${ }^{24}$

The key relevant provision of the Aarhus Convention is Article 9. This article sets key obligations in three major areas:

i. access to justice to challenge violations of access to environmental information requirements; ${ }^{25}$

ii. access to justice to challenge procedural or substantive legality of a decision, act or omission subject to public participation procedures, ${ }^{26}$

iii. access to justice to challenge acts or omissions by private persons or public authorities which contravene provisions of its national law relating to the environment. ${ }^{27}$

Unlike most of the provisions of the Aarhus Convention, Article 9(3) applies not merely to the acts and omissions of public authorities, but also to those of private persons. According to the Implementation Guide to the Convention, Article 9(3) has been introduced to give citizens standing to go to court or another review body to enforce environmental law. ${ }^{28}$ This provision appears to be the most complicated element of the Convention. Difficulties arise regarding its interpretation and the diversity of legal systems where this provision is supposed to apply.

23 Ensuring environmental access rights in the Caribbean: analysis of selected case-law (LC/TS.2018/31/ Rev.1), ECLAC and CCJ Academy of Law, Santiago, 2018, p. 43, [https://www.cepal.org/en/publications/43549-ensuring-environmental-access-rights-caribbean-analysis-selected-case-law], accessed 05. March 2020

24 Until now, there has been limited progress on the promotion of non-judicial dispute resolution as a means of finding effective solutions for disputes in the environmental field

25 Article 9(1)

26 Article 9(2): "Each Party shall, within the framework of its national legislation, ensure that member of the public concerned [...] have access to a review procedure before a court of law and/or another independent and impartial body established by law, to challenge the substantial and procedural legality of any decision, act or omission subject to the provisions of [...] this Convention"

27 Article 9(3)

28 Stec, S.; Casey-Lefkowitz, S., The Aarhus Convention, An Implementation Guide, United Nations, New York and Geneva, 2000, p. 130 
There is a misconception that the Aarhus Convention has to some degree provided a form of popular action (actio popularis) for environmental NGOs. ${ }^{29}$ The Convention did not introduce an actio popularis in environmental matters, but strengthened the status of environmental NGOs. Environmental NGOs having the status of the 'public concerned'30 are always deemed to have sufficient interest and to have rights capable of being impaired for the purpose of Article 9(2). The aim of this decision was to create an intermediate solution between the wide approach of an actio popularis and the strict approach according to which only those who are directly and/or individually concerned can have the right of access to justice.

\section{THE AARHUS CONVENTION IN EU LAW}

Within the EU, environment action programmes (EAPs) constitute the framework for the Union's environmental policy. Just like its predecessors, ${ }^{31}$ the Seventh Environmental Action Programme ( $7^{\text {th }}$ EAP) of the EU stresses the importance of public participation in environmental matters. In 1990, the Dublin European Council stressed that Community environmental legislation would only be effective if fully implemented and enforced by Member States. The European Commission acknowledged these shortcomings and repeatedly stressed the importance of public involvement in the enforcement of environmental law.

EU legislation in the field of the environment aims to preserve and improve the quality of the environment, and to protect human health. The objective of the Aarhus Convention is consistent with the objectives of EU environmental policy, listed in Article 174 TFEU. By ratifying the Aarhus Convention, the EU demonstrated its commitment at international level to ensuring adequate involvement of the public, and to guaranteeing broad access rights in environmental matters. When these rights and requirements are not applied consistently across the EU, progress may be hindered in achieving the EU's environmental objectives and present citizens from enjoying the full benefits of EU environmental laws.

As we mentioned, the European Community signed the Aarhus Convention on 25 June 1998, and approved it on 17 February 2005, just before the second Meet-

\footnotetext{
29 See the Opinion of AG Hogan in Case C-535/18 IL and Others v Land Nordrhein-Westphalen EU:C:2019:957, para. 34

30 The 'public concerned' is defined in Article 2(5) as "the public affected or likely to be affected by, or having an interest in, the environmental decision-making"

31 Decision No 1600/2002/EC laying down the Sixth Community Environment Action Programme [2002] OJ L 242/1, Fifth Community Action Programme for the Environment [1993] OJ C 138/1, Fourth Community Action Programme for the Environment [1987] OJ C 328/1
} 
ing of the Parties (MOP). ${ }^{32}$ In the meantime, relevant Community legislation was being made consistent with the Aarhus Convention. As the Commission noted, the Convention was the first international instrument which applied to the EU institutions and called it a "major political and legal development". ${ }^{33}$ It is clear that the Convention forms an integral part of the EU legal order, ${ }^{34}$ and it is binding upon the institutions of the EU and on its Member States pursuant to Article 216(2) TFEU. In accordance with settled case-law, mixed agreements concluded by the EU, its Member States and non-member countries have the same status in the legal order of the Union as purely EU agreements in so far as the provisions fall within the scope of Union competence. ${ }^{35}$

The EU has already adopted a comprehensive set of legislation, which is evolving and relates to not only its own institutions and bodies, but also the public authorities in the Member States. Not only judicial protection, but also access to information and participation procedures at $\mathrm{EU}$ and national levels has been amended to meet the Aarhus commitments. Directive 2000/60/EC establishing a framework for Community action in the field of water policy ${ }^{36}$ and Directive 2001/42/EC on the assessment of the effects certain plans and programmes on the environment ${ }^{37}$ were already adopted in line with the Aarhus Convention, but some, mainly older, environment-related Directives needed amendment to improve or include public participation provisions. Directive 2003/4/EC on public access to environmental information ${ }^{38}$ also paved the way towards the conclusion of the Aarhus Convention by implementing the obligations arising from the first pillar of the Convention (access to information) into EU law. The Commission made proposals for another directive on public participation in the drawing up of plans and programmes relating to the environment and amending Directives 85/337/EEC and 96/61/EC. ${ }^{39}$

\footnotetext{
32 Council Decision 2005/370/EC [2005] OJ L 124/1

33 European Commission press statement, 23 June 1998

34 Case C-470/16 North East Pylon Pressure Campaign Limited and Maura Sheehy v An Bord Pleanála and Others EU:C:2018:185, para. 46

35 See Case Meryem Demirel v Stadt Schwäbisch Gmünd (C-12/86, EU:C:1987:400, 9)

36 [2000] OJ L 327/1

$37 \quad$ [2001] OJ L $197 / 30$

38 [2003] OJ L 41/26

39 Directive 2003/35 providing for public participation in respect of the drawing up of certain plans and programmes relating to the environment and amending with regard to public participation and access to justice Council Directives 85/337/EEC and 96/61/EC [2003] OJ L 156/17
} 
On 24 October 2003 the Commission adopted an 'Aarhus package' of three legislative proposals to align Community legislation with the requirements of the Convention. The legislative package consisted of three different proposals:

i. Proposal for a Regulation of the European Parliament and of the Council on the application of the provisions of the Aarhus Convention on Access to information, Public Participation in Decision-making and Access to Justice in Environmental Matters to EC institutions and bodies, ${ }^{40}$

ii. Proposal for a Directive of the European Parliament and of the Council on access to justice in environmental matters, ${ }^{41}$

iii. Proposal for a Council Decision on the conclusion, on behalf of the European Community, of the Convention on access to information, public participation in decision making and access to justice regarding environmental matters. ${ }^{42}$

Legislative acts adopted by the EU institutions (both Directives and the 'Aarhus Regulation ${ }^{3 / 3}$ ) contain provisions on access to justice. This means that in the fields covered by Article 9(3) of the Convention, the EU has exercised its powers and adopted provisions to implement the obligations, which derive from it. ${ }^{44}$

\section{ARTICLE 263 TFEU AND CASE ACCC/C/2008/32}

Environmental concerns are traditionally viewed as an area appropriate for intervention by governments and/or international organisations, but cannot readily be conceived of as a right directly enforceable before the courts. It is well-known that the rules on legal standing (locus standi) for annulment actions brought by private persons enshrined in Article 230 of the EC Treaty were regarded as excessively restrictive. The Treaty of Lisbon tried to address this problem by adding a final limb that is now Article 263(4) TFEU, ${ }^{45}$ but the current situation is still that

\footnotetext{
$40 \operatorname{COM}(2003) 622$

$41 \operatorname{COM}(2003) 624$

$42 \operatorname{COM}(2003) 625$
}

43 Regulation (EC) No 1367/2006 on the application of the provisions of the Aarhus Convention on Access to Information, Public Participation and Access to Justice in Environmental Matters to Community institutions and bodies [2006] OJ L 264/13

44 Pánovics, A.; Odobaša, R., Environmental rights in the context of three legal systems - stepping into the EU legislature's shoes?, in: Drinóczi, T. et al. (eds.), Contemporary legal challenges: EU - Hungary Croatia, Faculty of Law, University of Pécs and Faculty of Law, J. J. Strossmayer University of Osijek, Pécs - Osijek, 2012, pp. 732-733

45 Oliver, P., Access to Information and to Justice in EU Environmental Law: The Aarhus Convention, Fordham International Law Journal, vol. 36, Issue 5, 2013, p. 1461 
environmental NGOs generally do not have legal standing in front of the Court of Justice of the EU. ${ }^{46}$

Regarding the Aarhus Regulation, it deals with all three pillars of the Convention in one piece of legislation, and it covers any public institution, body, office or agency established by, or on the bases of, the EU Treaties. ${ }^{47}$ Under Article 2 of the Regulation, an 'applicant' means any natural or legal person requesting environmental information, and 'the public' means one or more natural or legal persons, and associations, organisations or groups of such persons. Under Article 10(1), any non-governmental organisation which meets the criteria set out in Article 11 is entitled to make a request for internal review to the EU institution or body which has adopted an administrative act under environmental law. An 'administrative act' is defined as any measure of individual scope under environmental law, taken by a Community institution or body, and having legally binding and external effects. ${ }^{48}$ Article 11(1) lays down four conditions in that regard. According to the first condition, the NGO in question must be an independent nonprofit-making legal person in accordance with a Member States' national law or practice. ${ }^{49}$ Moreover, the NGO must have the primary stated objective of promoting environmental protection, there is a need for an existence for more than two years as an active NGO, and the subject-matter in respect of which the request for internal review is made has to be covered by its objective and activities. ${ }^{50}$

Unfortunately, the internal review procedure set out by the Aarhus Regulation has been interpreted restrictively by the EU institutions. The Regulation could not successfully combine requirements of Article 9(3) of the Convention with Article 263(4) TFEU, in particular, how to assure that environmental organisations can file lawsuits in the public interest, while not being 'directly and individually concerned'. ${ }^{51}$ Access to judicial review has remained possible only in accordance

46 Pánovics, A., The Paraquat Cases - Why is Article 230 Interpreted against European Environment Protection Organisations?, JURA, 2007, no. 2, p. 122

47 Article 2 (1) (c)

48 Article $2(1)(\mathrm{g})$

49 It is settled case-law that under the EU judicial system, an applicant is a legal person if, at the latest by the expiry of the period prescribed for proceedings to be instituted, it has acquired legal personality, in accordance with the law governing its constitution, or if it has been treated as an independent legal entity by the EU institutions; see Case T-168/13 European Platform Against Windfarms (EPAW) v European Commission EU:T:2014:47, par. 23

$50 \quad$ See points Article11 (1) (b)-(d)

51 Jendrośka, J., Public Information and Participation in EC Environmental Law, in: Macrory, R. (ed.), Reflections on 30 Years of EU Environmental Law - A High Level of Protection?, The Avosetta Series (7), Europa Law Publishing, 2006, p. 83 
with the Articles of the EC Treaty. ${ }^{52}$ This means that currently, the Aarhus Regulation does not guarantee adequate access to the Court of Justice of the EU.

In Case Stichting Natuur en Milieu and Pesticide Action Network Europe v Commis$\operatorname{sion}^{53}$ the General Court found that the Aarhus Regulation, by excluding general EU acts from the scope of internal review, was in breach of Article 9(3) of the Convention, but the Court of Justice overruled the General Court by holding that the Aarhus Regulation could not be reviewed in light of the Convention. ${ }^{54}$ With its refusal to use Article 9(3) as a reference criterion for the purpose of reviewing the EU's compliance with its international obligations, the Court of Justice avoided tackling the unsatisfactory level of judicial protection in environmental cases at Union level.

In March 2017, after extensive and detailed consideration of a communication that was submitted by an environmental NGO ${ }^{55}$ in 2008, the Compliance Committee of the Aarhus Convention found that the European Union was in noncompliance with the Convention due to the very limited possibilities for citizens and NGOs to have access to justice at EU level and to bring cases before the Court of Justice of the EU. The findings and the recommendations of the ACCC, while non-binding in themselves, have not made matters less complicated by reiterating the substantive shortcomings of the EU legal system in view of the requirements of the Aarhus Convention. ${ }^{56}$

The effectiveness of the ACCC relies heavily on cooperation by the Party experiencing difficulties in complying. Upon recommendations of the Compliance Committee, the MOP makes final decisions on compliance issues. ${ }^{57}$ The ACCC's power to adapt recommendations directly towards the Parties to the Convention is severely limited by the requirement of consent by the latter. ${ }^{58}$ At MOP-6, the

\footnotetext{
52 See Article 12 of the Aarhus Regulation

53 Case T-338/08 Stichting Natuur en Milieu and Pesticide Action Network Europe v Commission EU:T:2012:300

54 Joined Cases C-404/12 P and C-405/12 P Concil and Commission v Stichting Natuur en Milieu and Pesticide Action Network Europe EU:C:2015:5

55 ClientEarth is a charity that uses the power of law to protect the environment, by making sure laws are effective and enforcing them rigorously. It has over 160 staff working on projects in more than 50 countries

56 Shoukens, H., Access to Justice before EU Courts in Environmental Cases against the Backdrop of the Aarhus Convention: Balancing Pathological Stubbornness and Cognitive Dissonance?, in: Voigt, C. (ed.), International Judicial Practice on the Environment: Questions of Legitimacy, Cambridge University Press, 2019, p. 109

57 The findings of the ACCC have to be endorsed by the Meetings of the Parties (MOPs).

58 Pitea, C., Procedures and Mechanisms for Review of Compliance under the 1998 Aarhus Convention Access to Information, Public Participation in Decision-making and Access to Justice in Environmental Matters,
} 
Parties to the Convention - including the EU - discussed adopting the findings of the ACCC, and rejected the EU's proposal not to adopt the findings that the $\mathrm{EU}$ is breaching the Convention by preventing the members of the public from challenging the EU institutions' environmental decisions in court. The EU has been heavily criticized for its failure to accept an international panel's ruling; environmental NGOs expressed their deep concern at the response of the EU to the findings of the ACCC. ${ }^{59}$ As no other Parties supported the position of the EU, the resulting stand-off let to the matter being postponed to the next session of the MOP. ${ }^{60}$

\section{THE PROPOSAL FOR A NEW DIRECTIVE ON ACCESS TO JUSTICE}

Despite of the fact that the authors of the EU Treaties enacted not only Article 263(4) TFEU but also Article 19(1) TEU, obliging national courts ${ }^{61}$ to provide sufficient remedies to ensure an effective judicial remedy, a more general provision on access to justice covering all environmental matters, transposing the requirements of Article 9(3) is currently lacking. In 2003, the proposal of the European Commission set out a framework of minimum standards on legal standing that allowed the maintenance of national systems providing for broader legal standing. These minimum requirements were intended both to promote compliance with the Aarhus Convention and to harmonise legislation in the Member States, with a view to preventing situations of inequality between economic operators and national authorities. However, the proposal did not gather sufficient support from the representatives of the Member States in the Council. Finally, the Commission withdrew the proposal in $2014 .{ }^{62}$ This is the main reason why specific provisions aimed at ensuring reasonable access to justice are currently restricted to a few areas of EU environmental law. ${ }^{63}$

It is necessary to consider the implementation of Article 9(3) at national level separately from implementation with regard to the acts of the EU institutions and

in: Treves, T. et al. (eds.), Non-Compliance Procedures and Mechanisms and the Effectiveness of International Environmental Agreements, T.M.C. Asser Press, The Hague, 2009, p. 241

59 [http://eeb.org/eu-slammed-for-lack-of-respect-for-rule-of-law-on-environmental-justice/], accessed 18. March 2020

60 Pánovics, A., Case ACCC/C/2008/32 and Non-compliance of the EU with the Aarhus Convention, Pécs Journal of International and European Law, no. 2, 2017, p. 17

${ }_{61}$ National courts are to be approached as 'ordinary courts' for implementing and enforcing EU law within the legal systems of the Member States

62 Withdrawal of obsolete Commission proposals [2014] OJ C 153/3

$63 \operatorname{COM}(2012) 95$ final, p. 9 
bodies. Both the Aarhus Convention and EU legislation allow Member States to afford standing to environmental NGOs only if they fulfil certain criteria. EU Member States belong to different traditions with some of them granting a broad access to justice (including actio popularis that gives the possibility to everybody to act in favour of the environment); others have a more limited approach. The majority of the Member States continue to require an 'interest' of the applicant for seeking judicial redress. Upon signature of the Aarhus Convention, the European Union made a declaration that EU Member States will remain responsible for the performance of obligations until Article 9(3) concerning acts and omissions by private persons or public authorities other than the EU institutions and bodies, until the adoption of EU legislation covering these obligations. As a result, the admissibility of legal actions commenced by NGOs is in nearly all Member States contingent upon additional standing requirements. Some Member States set stringent criteria requiring, for example, a minimum number of members or that an NGO has pursued its environmental objectives for a certain period of time.

Since the 1990s, national courts have been asking the Court of Justice to clarify how they should deal with the different guarantees of access to justice. In the famous Slovak Bears (VLK) case, the Court of Justice has held that "a specific issue which has not yet been the subject of EU legislation is part of EU law, where that issue is regulated in agreements concluded by the European Union and the Member States and it concerns a field in large measure covered by it". Furthermore, the Court confirmed that national courts must interpret access to justice rules in a way which is compliant with the Aarhus Convention. ${ }^{64}$ By denying direct effect to Article 9(3), the Court of Justice failed to fully empower environmental NGOs to enforce this provision before the national courts, and instead relied on the cooperation of the national courts to interpret national procedural law in a way which could realise the objectives of the Aarhus Convention. ${ }^{65}$

In 2012, a study discussed four options to consider for future actions. The first option was to enact a new directive reflecting the legal regime of the Member States concerning the locus standi of environmental NGOs and the case-law of the Court of Justice of the EU. The second option was to reiterate the original proposal of the Commission. Third, the use of soft law instruments to promote collaboration between national courts, possibly supplemented by guidelines. Finally, the

64 Case C-204/09 Lesoochranárske zoskupenie VLKv Ministerstvo životného prostredia Slovenskej republiky EU:C:2011:125, paras. 36 and 51

65 Eliantonio, M., The role of NGOs in environmental implementation conflicts: 'stuck in the middle' between infringement proceedings and preliminary rulings?, Journal of European Integration, vol. 40, no. 6, 2018, p. 760 
infringement proceeding was suggested as a tool to promote compliance with the requirements of the Court's case-law.

On 28 April 2017, the Commission adopted an interpretative guidance document that brings together and explains 38 rulings of the Court of Justice in order to help individuals, NGOs, businesses, public administrators and national courts understand access to justice in environmental matters. ${ }^{66}$ The scope of the "Notice ${ }^{97}$ is limited to access to justice in relation to decisions, acts and omissions by public authorities of the Member States. ${ }^{68}$ It does not concern the judicial review of acts of the EU institutions. In this way, Member States and their judiciaries may better understand the content and significance of the Court's new case-law. In 2019, DG Environment published a Citizen's Guide on access to justice in environmental matters. ${ }^{69}$

According to access to justice in environmental matters, the evaluation of the $7^{\text {th }}$ EAP concludes that "significant barriers still exist in several Member States", and "the emerging evidence base indicates that more needs to be done at Member State level" ${ }^{70}$ It seems to be evident that the adoption of a new directive defining the conditions for effective as well as efficient access to national courts in respect of all areas of EU environmental law would contribute to facilitating access to justice at national level, and stimulating cooperation and dialogue between national authorities and courts. A directive on access to justice in environmental matters would mean a harmonized regime of access to justice in all Member States and would guarantee the same rights to the members of the public throughout the European Union.

\section{ACCESS TO JUSTICE IN CLIMATE CHANGE LITIGATION}

At international level, the Paris Agreement has been established as the core element of the climate change governance framework. It resembles a central legal management for global efforts concerning climate change mitigation and adaptation. ${ }^{71}$ Despite of the fact that access to justice is absent from the international

\footnotetext{
66 C(2017) 2616 final [2017] OJ C 275/1

67 This is the first ever interpretative communication in EU environmental law

68 National authorities are a key to the delivery of EU environmental legislation and the achievement of tangible results

${ }_{69}$ [https://ec.europa.eu/environment/aarhus/pdf/guide/ENV-18-004_guide_EN_web.pdf], accessed 12. April 2020

$70 \operatorname{SWD}(2019)$ 181, PART 2/2, p. 198

71 Wegener, L., Can the Paris Agreement Help Climate Change Litigation and Vice Versa?, Transnational Environmental Law, vol. 9, Issue 1, 2020, p. 19
} 
climate change treaty regime, judicial activism appears to be emerging in national climate change cases. ${ }^{72}$ Until recently, more activist types of legal actions in climate cases had little chance of success in view of the rigid standing rules that often prevailed before the courts in the context of public interest litigation. The past few years have seen a remarkable shift in the jurisprudential approach to the traditional standing requirements in environmental cases, which seem to offer more perspective for judicial activism in the realm of climate litigation. Faced with the severe impacts of climate change, the members of the public might be found increasingly willing to sue their governments over the failure to adopt adequate and ambitious programmes.

On 20 December 2019, the Dutch Supreme Court upheld the previous decisions in the Urgenda Climate Case, ${ }^{73}$ finding that the Dutch government has obligations to urgently and significantly reduce emissions in line with its human rights obligations. On the basis of the rather broadly formulated 'duty of care' contained in the Dutch Civil Code, the Dutch government was ordered to step up its efforts in combating climate change in the ground-breaking Urgenda ruling. This was the first case in the world in which citizens ${ }^{74}$ established that their government had a legal duty to prevent dangerous climate change. Since the Dutch case, climate change cases have been filed worldwide, demonstrating the power of holding governments accountable in court.

As of today, similar actions have not received a favourable treatment before the CJEU, in particular because of its restrictive and conservative jurisprudence in terms of the individual concern criterion, known as 'the Plaumann test'. In May 2018, several families brought an action before the General Court for annulment and compensation for insufficient measures to combat climate change ("The People's Climate Case"). ${ }^{75}$ The applicants challenged parts of several pieces of EU legislation to comply with the nationally determined contributions (NDCs) under the Paris Agreement, asking the General Court to rule on the protection of their fundamental rights such as the right to life, health, occupation and property. As might be expected, the General Court ruled, in its order of 8 May 2019, that the

72 Colombo, E., (Un)comfortably Numb: The Role National Courts for Access to Justice in Climate Matters, in: Jendrośka, J.; Bar, M. (eds.), Procedural Environmental Rights, Principle X in Theory and Practice, European Environmental Law Forum Series, Volume 4, Intersentia Ltd, Cambridge - Antwerp - Portland, 2017, p. 437

73 An English translation of the judgment is available here: [https:/www.urgenda.nl/wp-content/uploads/ ENG-Dutch-Supreme-Court-Urgenda-v-Netherlands-20-12-2019.pdf], accessed 01. May 2020

74 The Urgenda Foundation represented 886 plaintiffs

75 Case T-330/18 Armando Carvalho and Others v European Parliament and Council of the EU EU:T:2019:324 
action was inadmissible. ${ }^{76}$ This ruling reasserts the settled case-law of the Court of Justice of the EU, and confirms the long-standing irony that, under the current interpretation of Article 263(4) TFEU, the more widespread the harmful effects of an EU act, the more restricted the access to justice. The more serious the damage and the higher the number of affected persons, the less judicial protection is available. ${ }^{77}$

Against this backdrop, environmental enforcement through court proceedings comes into the picture as an attractive alternative. Taking into account the progressive case-law evolutions in the context of clean air litigation both before the CJEU and national courts, ${ }^{78}$ it appears no longer unthinkable to bring forward complex issues like climate claims in court.

\section{CONCLUSION}

Over the years, the Aarhus Convention and the European Union have mutually reinforced and developed each other. The interplay between EU law and the Convention have been subject to numerous accounts in academic literature, including the double standards applied by the EU institutions in this area. ${ }^{79}$ The present situation in EU law as far as access to justice in environmental matters is rather complex. EU legal instruments in force do not cover fully the implementation of the obligation resulting from Article 9(3) of the Convention.

In September 2017, the European Parliament called on the Commission to come forward with a new legislative proposal on minimum standards for access to judicial review, and expressed its preference for amending the Aarhus Regulation. ${ }^{80}$ On 11 June 2018, the Council of the EU requested the Commission under Article 241 TFEU to submit a study on the Union's options for addressing the findings of the ACCC. ${ }^{81}$ The Commission has evaluated the current situation and assessed options to address compliance to underpin possible decision-making. A new initiative of the Commission aims to amend EU rules to environmental associations who have concerns about an action (or lack of it) by EU institutions or bodies. On

\footnotetext{
76 An appeal is currently pending before the Court of Justice (see Case C-565/19 P)

77 [https://www.clientearth.org/the-general-court-rejects-the-people-climate-case-as-inadmissible/], accessed 28 March 2020

78 See in this regard, for instance, Case C-752/18 Deutsche Umwelthilfe eV $v$ Freistaat Bayern EU:C:2019:1114

79 Krämer, L., Access to Environmental Justice: the Double Standards of the ECJ, Journal of European Environmental \& Planning Law, vol. 14, Issue 2, 2017, pp. 159-185

80 P8_TA(2017)0441

$81 \quad 9422 / 18$
} 
6 March 2020, the Commission published a Roadmap proposing an amendment of the Arhus Regulation. The proposal for a new regulation "should also improve access to national courts, in all EU countries". ${ }^{82}$

SOER 2020 shows that despite the relative success of EU environmental policy, ${ }^{83}$ the outlook for the European environment is discouraging. Taking into account the overarching vision and complementing policy targets set out in the $7^{\text {th }} \mathrm{EAP}$, it is clear that the EU is not making enough progress in addressing environmental challenges. There is a need to strengthen the implementation of environmental policy to achieve its full benefits. The lack of legal standing of private persons before the Court of Justice remains part of the democratic deficit of the EU. The Court of Justice needs to address this deficit, and the adoption of a new directive on access to justice could create space for governments to bring a new scale of ambition to environmental policies and actions. Europe must seize the opportunities, using every means available to deliver transformative changes in the coming decade, including new ways to leverage the powers of citizens and environmental NGOs.

\section{REFERENCES}

\section{BOOKS AND ARTICLES}

1. Andrusevych, A.; Caroline Jo, C., Sustainable development concerns at the Aarhus Convention Compliance Committee, in: Cordonnier Segger, M.-C. (ed.): Sustainable Development Principles in the Decisions of International Courts and Tribunals, Routledge, 2017, pp. 723-737

2. Cameron, J.; MacKenzie, R., Access to Environmental Justice and Procedural Rights in International Institutions, in: Boyle, A. E.; Anderson M. R. (eds.), Human Rights Approaches to Environmental Protection, Oxford University Press, 1996, pp. 129-152

3. Colombo, E., (Un)comfortably Numb: The Role National Courts for Access to Justice in Climate Matters, in: Jendrośka, J.; Bar, M. (eds.), Procedural Environmental Rights, Principle X in Theory and Practice, European Environmental Law Forum Series, Volume 4, Intersentia Ltd, Cambridge - Antwerp - Portland, 2017, pp. 437-464

4. Darpö, J., Principle 10 and access to justice, in: Krämer, L.; Orlando, E. (eds.), Elgar Encyclopedia of Environmental Law, Edward Elgar Publishing, 2018, pp. 379-402

5. Ebbesson, J., The Notion of Public Participation in International Environmental Law, Yearbook of International Environmental Law, vol. 8, 1997, pp. 75-81

82 [https://ec.europa.eu/info/law/better-regulation/have-your-say/initiatives/12165-Access-to-Justice-in-Environmental-matters], accessed 14. April 2020

83 EU environmental policy has been more effective in reducing environmental pressures than in protecting natural resources and human health 
6. Eliantonio, M., The role of NGOs in environmental implementation conflicts: 'stuck in the middle between infringement proceedings and preliminary rulings?, Journal of European Integration, vol. 40, no. 6, 2018, p. 753-767

7. Jendrośka, J., Public Information and Participation in EC Environmental Law, in: Macrory, R. (ed.), Reflections on 30 Years of EU Environmental Law - A High Level of Protection?, The Avosetta Series (7), Europa Law Publishing, 2006, pp. 63-85

8. Krämer, L., Access to Environmental Justice: the Double Standards of the ECJ, Journal of European Environmental \& Planning Law, vol. 14, Issue 2, 2017, pp. 159-185

9. Odermatt, J., The Development of Customary International Law by International Organizations, International and Comparative Law Quarterly, vol. 22, Issue 2, 2017, pp. 1-24

10. Oliver, P., Access to Information and to Justice in EU Environmental Law: The Aarhus Convention, Fordham International Law Journal, vol. 36, Issue 5, 2013, pp. 1423-1470

11. Pánovics, A., The Paraquat Cases - Why is Article 230 Interpreted against European Environment Protection Organisations?, JURA, No. 2, 2007, pp. 122-132

12. Pánovics, A.; Odobaša, R., Environmental rights in the context of three legal systems - stepping into the EU legislature's shoes?, in: Drinóczi, T. et al. (eds.), Contemporary legal challenges: EU - Hungary - Croatia, Faculty of Law, University of Pécs and Faculty of Law, J. J. Strossmayer University of Osijek, Pécs - Osijek, 2012, pp. 723-742

13. Pánovics, A., Case ACCC/C/2008/32 and Non-compliance of the EU with the Aarhus Convention, Pécs Journal of International and European Law, 2017, No. 2, pp. 6-18

14. Pitea, C., Procedures and Mechanisms for Review of Compliance under the 1998 Aarhus Convention Access to Information, Public Participation in Decision-making and Access to Justice in Environmental Matters, in: Treves, T. et al. (eds.), Non-Compliance Procedures and Mechanisms and the Effectiveness of International Environmental Agreements, T.M.C. Asser Press, The Hague, 2009, pp. 221-249

15. Richardson, B. J.; Razzaque, J., Public Participation in Environmental Decision-Making, in: Richardson, B. J.; Wood, S. (eds.), Environmental Law for Sustainability, Hart Publishing, Oxford, 2006, pp. 165-194

16. Shoukens, H., Access to Justice before EU Courts in Environmental Cases against the Backdrop of the Aarhus Convention: Balancing Pathological Stubbornness and Cognitive Dissonance?, in: Voigt, C. (ed.), International Judicial Practice on the Environment: Questions of Legitimacy, Cambridge University Press, 2019, pp. 74-118

17. Stec, S.; Casey-Lefkowitz, S., The Aarhus Convention, An Implementation Guide, United Nations, New York and Geneva, 2000

18. Wegener, L., Can the Paris Agreement Help Climate Change Litigation and Vice Versa?, Transnational Environmental Law, vol. 9, Issue1, 2020, pp. 17-36

\section{COURT OF JUSTICE OF THE EUROPEAN UNION}

1. Case T-338/08 Stichting Natuur en Milieu and Pesticide Action Network Europe v Commission EU:T:2012:300

2. Case C-115/09 Bund für Umwelt und Natuurschutz Deutschland, Landesverband NordrheinWestfalen eVv Bezirksregierung Arnsberg EU:C:20111:289 
3. Case C-204/09 Lesoochranárske zoskupenie VLKv Ministerstvo životného prostredia Slovenskej republiky EU:C:2011:125, paras. 36 and 51

4. Joined Cases C-404/12 P and C-405/12 P Concil and Commission v Stichting Natuur en Milieu and Pesticide Action Network Europe EU:C:2015:5

5. Case T-168/13 European Platform Against Windfarms (EPAW) v European Commission EU:T:2014:47, par. 23

6. Case C-470/16 North East Pylon Pressure Campaign Limited and Maura Sheehy v An Bord Pleanála and Others EU:C:2018:185, para. 46

7. Case T-330/18 Armando Carvalho and Others $v$ European Parliament and Council of the EU EU:T:2019:324

8. Opinion of AG Hogan in Case C-535/18 IL and Others $v$ Land Nordrhein-Westphalen EU:C:2019:957, para. 34

9. Case C-752/18 Deutsche Umwelthilfe eV v Freistaat Bayern EU:C:2019:1114

\section{EU LAW}

1. Council Decision 2005/370/EC on the conclusion, on behalf of the European Community, of the Convention on access to information, public participation in decision-making and access to justice in environmental matters [2005] OJ L 124/1

2. Directive 2000/60/EC establishing a framework for Community action in the field of water policy [2000] OJ L 327/1

3. Directive 2001/42/EC on the assessment of the effects certain plans and programmes on the environment [2001] OJ L 197/ 30

4. Directive 2003/4/EC on public access to environmental information and repealing Council Directive 90/313/EC [2003] OJ L 41/26

5. Directive $2003 / 35$ providing for public participation in respect of the drawing up of certain plans and programmes relating to the environment and amending with regard to public participation and access to justice Council Directives 85/337/EEC and 96/61/EC [2003] OJ L $156 / 17$

6. Regulation (EC) No 1367/2006 on the application of the provisions of the Aarhus Convention on Access to Information, Public Participation and Access to Justice in Environmental Matters to Community institutions and bodies [2006] OJ L 264/13

\section{WEBSITE REFERENCES}

1. COWI and Eunomia, Study: The costs of not implementing EU environmental law, Final Report, 2019, [https://ec.europa.eu/environment/eir/pdf/study_costs_not_implementing env_law.pdf], accessed 21. March 2020

2. Ensuring environmental access rights in the Caribbean: analysis of selected case-law (LC/ TS.2018/31/Rev.1), ECLAC and CCJ Academy of Law, Santiago, 2018, p. 43, [https:/www. cepal.org/en/publications/43549-ensuring-environmental-access-rights-caribbean-analysis-selected-case-law], accessed 05. March 2020 
3. Special Eurobarometer 501: Attitudes of European citizens towards the Environment, Summary, December 2019, p. 28, [https://data.europa.eu/euodp/en/data/dataset/S2257_92_4_501_ ENG], accessed 18. March 2020

4. The European environment - state and outlook, Knowledge for transition to a sustainable Europe, European Environment Agency, 2019, p. 7, [https://www.eea.europa.eu/soer], accessed 23. March 2020 